\title{
Kategoria instytucjonalizmu w tworzeniu regionalnych systemów innowacyjnych
}

https://doi.org/10.33141/po.2005.78.06

\section{Arkadiusz Świadek}

Przegląd Organizacji, Nr 7/8 (786/787), 2005, ss. 26-29

www.przegladorganizacji.pl Towarzystwo Naukowe Organizacji i Kierownictwa (TNOiK)
Zrozumienie i akceptacja rozwoju innowacji jako interaktywnego procesu uczenia się zakwestionowały zasadniczo hipotezę o dominującej roli liniowej koncepcji procesu innowacyjnego ${ }^{1)}$. Modelowanie regionalnych systemów innowacyjnych opiera się mniej na idei innowacji, częściej natomiast na procesowości tego zjawiska, a szerzej dynamizmie systemowym ${ }^{2}$. Podejście liniowe do procesu innowacyjnego jest wykorzystywane jako uproszczony model rzeczywistości (politycznie poprawny), celem subiektywnej możliwości na niego oddziaływania i stymulowania przez instrumenty polityki makroekonomicznej. To uproszczone założenie prowadzi do niskiej efektywności systemu innowacyjnego jako całości. Jest to niestety wynik niezrozumienia fenomenu, jakim sa procesy innowacyjne. To jednocześnie kolejny dowód (nie wprost) podważający nie tyle chęć, co możliwość sterowania mechanizmami rządzącymi procesami innowacyjnymi w skali makro (narodowej).

Nie angażując się w szczegółowe rozpatrywanie modeli procesu innowacyjnego, można stwierdzić, że obecnie akceptowany jest model S.J. Kline'a i N. Rosenberga, który zakłada endogeniczność, dynamiczność i nieliniowość, co odrzuca lub ogranicza możliwość stosowania tradycyjnych modeli liniowych. Powszechnie akceptowany model związanego łańcucha jest ważną przesłanką w budowie regionalnego systemu innowacyjnego. Zrozumienie jego istoty, akceptacja wewnętrznej synergii, wzajemnych wewnętrznych interakcji, roli instytucji pośredniczących, różno- i wieloetapowości w kreowaniu innowacji jest warunkiem koniecznym do stworzenia opartego na nowych technologiach efektywnego, dynamicznego i kumulatywnego systemu transferu wiedzy w regionie.

System innowacyjny to nie tylko suma elementów, z których się składa. Kluczowe znaczenie dla jego sprawności mają głównie interakcje między tymi elementami (czynnikami) ${ }^{3}$. Jedne z pierwszych badań nad wymiarem przestrzennym systemu innowacyjnego przeprowadził blisko 100 lat temu Alfred Marshall ${ }^{4}$. Wprowadził on pojęcie dystryktów przemysłowych (okręgów). To badanie dowiodło, że lokalizacja przestrzenna wpływa na proces uczenia się organizacji przez mechanizm wzajemnych związków, na przykład wzrost prawdopodobieństwa spotkań (relacji) między różnymi uczestnikami w systemie innowacyjnym ${ }^{5)}$.
Nowe okręgi przemysłowe zidentyfikowano na przełomie lat 70. i 80. XX wieku w północno-wschodnich i środkowych Włoszech, gdzie przedsiębiorstwa przyswajały nowe technologie łatwiej i szybciej, dostosowując się do zmian światowej gospodarki ${ }^{6}$. Korzyści wynikające z kombinacji elastyczności ze specjalizacją były tworzone wzdłuż lokalnego łańcucha wartości bazującego na współpracy w obrębie okręgu przemysłowego.

U podstaw prób poznania (zgłębiania) regionalnych systemów innowacyjnych (RSI) leżą instytucjonalne i neoinstytucjonalne teorie firmy. Do najważniejszych z nich zaliczamy ${ }^{7}$ : teorię klasy próżniaczej T. Veblena, teorię kosztów transakcyjnych R. Coase'a, teorię kontraktualną firmy, teorię agencji czy neoinstytucjonalną teorię przedsiębiorstwa $\mathrm{O}$. Williamsona. Nie angażując się i nie przybliżając w szczegółach znaczenia i dorobku poszczególnych podejść można stwierdzić, że dały one fundamenty pod budowę zasad tworzenia i zrozumienia istoty regionów innowacyjnych. Funkcjonowanie mechanizmów na rynku nie opisywanych przez ekonomię neoklasyczną pozwoliło rzucić inne nowe światło na funkcjonowanie rynku i jego organizacji. Szczegółowej analizie poddano przedsiębiorstwo, jako podmiot rynkowy o określonych celach, zachowaniach i strukturze w przeciwieństwie do „czarnych skrzynek” szkoły klasycznej i neoklasycznej.

Interpretacja wyrażenia ,instytucjonalizm” budzi obecnie wiele wątpliwości. W centrum uwagi szkoły instytucjonalnej i neoinstytucjonalnej okazują się być nie tyle instytucje sensu stricto, lecz mechanizmy, sposoby i ramy zbiorowych działań. Niestety, w różnych opracowaniach ma miejsce zawężona i potoczna interpretacja zjawiska instytucji, przez co ich autorzy skupiają swoją uwagę na dopasowaniu mechanizmów stymulujących innowacje do istniejących struktur, a nie dostosowaniu struktur do pożądanych mechanizmów. Jest to oczywiste qui pro quo, które z założenia ogranicza możliwość efektywnego zbudowania regionalnego systemu innowacji opartego na zasadach tradycyjnego (czytaj teoretycznego) instytucjonalizmu. Dopełnieniem tego mylnego rozumowania niech będą próby odgórnego tworzenia i sterowania RSI, co jest sprzeczne z ideą „klastrów” powstających w drodze naturalnych mechanizmów popytowo-podażowych. $\mathrm{W}$ tym przypadku podejmuje się próby budowania 
konsensusu między wszystkimi zainteresowanymi stronami (key actors), co stanowi próbę quasi-oddolnego konstruowania rozwiązań proinnowacyjnych ${ }^{8}$. Mimo że metodologia budowania strategii innowacyjnych nakazuje badanie popytu i podaży technologii, to w różnych regionach w Europie naciski w tym obszarze były rozłożone nierównomiernie.

Dynamiczne zmiany, jakie mają miejsce w technologii i konkurencyjności, wymagają elastyczności zarówno przedsiębiorstw, jak i polityki innowacyjnej w regionie i kraju. Takim metodologicznie poprawnym podejściem do problematyki instytucjonalizmu była konstrukcja narodowego i sektorowego systemu innowacyjnego w Australii czy Kanadzie ${ }^{9}$, a na przeciwnym biegunie efektywności przypadek Austrii ${ }^{10)}$.

Koszty transakcji jako nieodłączny element instytucjonalizmu mogą być ograniczane przez zjawisko kooperacji11). Zmniejszają się tym samym koszty kreowania innowacji, a więc i koszty procesu innowacyjnego. Ze względu na różne ograniczenia występujące na drodze do kooperacji (np. niepewność, niezgoda itp.) istnieje potrzeba jej formalizacji, co również przyczynia się do podnoszenia kosztów ${ }^{12}$. Być może brzmi to jak paradoks, jednak jak pokazują doświadczenia różnych krajów i regionów koszty transakcji wynikające z konieczności formalizacji procesu kooperacji są niewspółmiernie niższe od kosztów, jakie ponosi się, gdy kooperacja jest zjawiskiem szczątkowym (incydentalnym).

Podsumowując część dotyczącą podejścia procesowego i instytucjonalnego można stwierdzić, że istnieją spore rozbieżności co do prawidłowej aplikacji (implementacji) tych fundamentów do systemów innowacyjnych, bez znaczenia jest w tym wypadku płaszczyzna krajowa czy regionalna. Synteza tych podejść daje prawidłowe ramy do konstrukcji i tworzenia systemów innowacyjnych (SI) opartych na etapach:

- identyfikacji mechanizmów rządzących innowacjami w ujęciu procesowym;

- wskazania słabości mechanizmów kreowania nowych wyrobów;

- propozycji zmian w istniejących schematach programów stymulowania postaw innowacyjnych w kraju lub regionie uwzględniających rozwiązania wpływające na redukcję kosztów transakcyjnych.

Spełnienie tych warunków stanowi nieodzowny element kreowania systemów innowacyjnych opartych na przesłankach procesowości, instytucjonalizmu, dynamizmu systemowego i jego efektywności.

Na podstawie wyżej przedstawionych wywodów (argumentacji) istotą teorii systemów innowacyjnych są zatem relacje między wewnętrznymi aktorami w regionie oraz ich integracja $\mathrm{z}$ zewnętrznymi sieciami międzyregionalnymi ${ }^{13)}$. W tym przypadku podejście (układ) terytorialne (milieu approach) to interakcje rozwijające się między uczestnikami regionu postrzegane jako proces nabywania wiedzy o wielostronnych transakcjach, które prowadzą do wygenerowania innowacyjnych dóbr i usług, i jako proces uczenia się o konwergencji w znaczeniu poprawy efektywności form współpracy zarządzania zasobami ${ }^{14)}$. Wzajemne związki i proces nabywania wiedzy nie są zadaniem prostym, na co wskazują badania prowadzone m.in. w Stanach Zjednoczonych, w których zwrócono uwagę na aspekt braku wspólnego systemu komunikowania między instytucjami wspomagającymi a pracodawcami $^{15)}$. Komplikacje wynikajace z problemu (zasady) talk the talk (mówienie o mówieniu), mimo istnienia fizycznej infrastruktury wspomagającej działalność innowacyjną, uniemożliwiają sprawny przepływ wiedzy, a zatem ograniczają interakcje, czego konsekwencja jest mało efektywny system innowacyjny w regionie.

Suma gier różnych uczestników instytucjonalnych i mikroorganizacji prowadzi do nowej ścieżki samopodtrzymującego się rozwoju opartego na inwestycjach niematerialnych, dostępie do informacji o umiejętnościach i dynamicznym rozwoju związanej z tym infrastruktury $^{16)}$. Badania nad interakcjami prowadzono również w krajach Ameryki Łacińskiej, gdzie skupiono się głównie na szkolnictwie wyższym, uznając jego nadrzędną rolę w regionalnym tworzeniu wiedzy ${ }^{17)}$. Czynniki przestrzenne (jak podaż wykwalifikowanej siły roboczej, badania, transfer technologii i konsulting), rynek i poziom konkurencji, trendy technologiczne w poszczególnych przemysłach, ryzyko współpracy sa tak samo istotnymi elementami środowiska biznesowego, jak polityka badawczo-rozwojowa ${ }^{18)}$. Związki kooperacji mogą mieć różne znaczenie dla transferu informacji:

- wysoki stopień kooperacji może korespondować z wysokim stopniem podziału pracy i specjalizacji biorąc pod uwagę działalność innowacyjną;

- współpraca może być postrzegana jako kanał transferu wiedzy - badania empiryczne wykazują, że efekty tego przepływu są skoncentrowane w ujęciu przestrzennym w zależności od rodzajów źródeł ${ }^{19)}$.

Elastyczna polityka stymulująca innowacje powinna być skupiona rzadziej na promowaniu zaawansowania naukowego i tworzenia innowacji w rozumieniu Schumpeterowskim, częściej natomiast na barierach dyfuzji i aplikacji. Taką optykę przyjęto w Komisji Europejskiej w UE ${ }^{20)}$. Implementacja właściwie dobranej mieszanki polityk i unikanie barier wywołanych koncentracją, w szczególności na poziomie regionalnym lub krajowym, wymaga stworzenia odpowiedniego systemu komunikacji i kooperacji między różnymi poziomami polityki przemysłowej. Jest to tak samo istotne jak obserwacja integracji międzynarodowych trendów rozwoju i regionalnych potrzeb ${ }^{21)}$. Ten typ podejścia próbowano implementować (aplikować) w Austrii w regionie Styrii, gdzie stworzono cztery rodzaje strategii ${ }^{22)}$ : $\bullet$ zwiększenia kooperacji, $\bullet$ wspierania absorpcji i dyfuzji nowych rozwiązań, • podnoszenia jakości i kwalifikacji kapitału ludzkiego, • reorganizacji instytucji odpowiedzialnych za politykę technologiczną.

Regionalne systemy innowacyjne powstały w Unii Europejskiej jako nowe ramy zarówno koncepcyjne, jak i operacyjne ${ }^{23)}$. Pierwsze ujęcie bazuje na perspektywie ewolucyjnej. To oznacza, że firmy nie są traktowane jako homogeniczne i atomistyczne jednostki (klasyczna ekonomia firm) ukierunkowane na maksymalizację różnych kategorii, lecz jako zróżnicowane jednostki zdolne do nauki zarówno na podstawie własnych doświadczeń, jak i od innych. Przedsiębiorstwa 
nie kreują innowacji w izolacji. W rzeczy samej relacje między firmami i innymi organizacjami są identyfikowalne jako istotne dla kształtowania procesów innowacyjnych ${ }^{24)}$. Dla ewaluacji RSI potrzebnych jest więcej analiz (badań) niż obszar między przedsiębiorstwami a sektorem B+R, co było podstawą debat nad transferem technologii od początku lat 80 . ub. stulecia. Liniowy model procesu innowacyjnego stworzył podstawy do prowadzonych analiz, co obecnie jest niewystarczające dla wyjaśnienia wysokiej elastyczności produkcji dóbr zaawansowanych technologicznie. Sieć innowacyjna w obszarze przedsiębiorstwa i publiczna sfera $B+R$ powinny być traktowane na równi z innymi relacjami (związkami). Z punktu widzenia perspektywy regionalnej istotne jest określenie udziału uczestników, którzy współdziałają w regionie, i tych którzy funkcjonują (oddziałuja) poza nim. Ta wewnętrzna gra między zróżnicowanymi uczestnikami z regionu i poza jest centralnym punktem koncepcji innowacyjnego otoczenia oraz teorii sieci innowacyjnych ${ }^{25)}$. Ujęcie operacyjne RSI jest obecnie manifestowane przez popularność programów regionalnych strategii innowacyjnych takich, jak: RITTS, RIS, RIS+, TRIP realizowanych w UE ${ }^{26)}$.

$\mathrm{Z}$ pojęciem systemu innowacyjnego wiąże się nierozerwalnie regionalny potencjał innowacyjny, rozumiany jako czynniki wspomagające i utrudniające możliwości innowacyjne region ${ }^{27)}$. Regionalny potencjał innowacyjny jest uzależniony od sieci informacyjnej (relatywnie prostej), sieci innowacyjnej (bardzo skomplikowanej) i sieci wiedzy (znajdujacej się między nimi, ale o rosnaccym znaczeniu) ${ }^{28)}$. Sieć innowacyjna nie jest immanentnie i permanentnie zdolna do tworzenia nowych wyrobów i technologii. Sukces firmy funkcjonującej w takiej sieci jest uzależniony od struktury zarządzania regionem. Wpływa to na poziom kosztów transakcyjnych (informacji i ryzyka) przez wzrost zaufania i powtarzalności relacji, co ogranicza „dylemat więźnia” i „moralne ryzyko” ${ }^{29)}$. Sieć powinna $z$ jednej strony wpływać pozytywnie na rozwój regionu, lecz z drugiej strony efekty regionalnej kooperacji zależą od konkretnych potrzeb oraz możliwości kooperacyjnych partnerów, którzy powinni na te potrzeby odpowiedziećso).

Inkubacja nowych produktów i procesów ma miejsce $\mathrm{w}$ regionach metropolitarnych, co określane jest brzegiem konkurencyjności regionu ${ }^{31}$. Kontakty przedsiębiorstw przemysłowych z zewnętrznymi ośrodkami badawczymi i instytutami są natomiast istotą rozwoju konkurencyjności i umiejętności innowacyjnych, szczególnie w regionach peryferyjnych ${ }^{32}$.

Należy pamiętać, że podejście RSI zakłada istnienie odmienności charakterystyk technologicznych regionów. Tymczasem przypadek biotechnologii w Australii i Austrii, czyli dublowania nakładów i zadań $\mathrm{B}+\mathrm{R}$, pokazuje, że różne substytucyjne regiony moga działać szkodząc sobie wzajemnie. To sugeruje konieczność występowania polityki o zasięgu krajowym, pełniącej funkcje głównie koordynacyjne. Innym często popełnianym błędem jest próba ograniczenia identyfikacji interakcji do przedsiębiorstw przemysłowych w regionie, co w przypadku regionów o przestarzałej, archaicznej czy tradycyjnej strukturze przemysłowej traci sens, praktyka światowa dowodzi bowiem istnienia bardzo innowacyjnych usług okołoprzemysłowych. To spostrzeżenie pozwala rozszerzyć dotychczasowe spektrum rozważań o inne relacje, co ma szczególne znaczenie dla regionów polskich.

dr Arkadiusz Świadek

Instytut Ekonomiki i Organizacji Przedsiębiorstw Uniwersytetu Szczecińskiego

\section{PRZYPISY}

1) CH. EDQUIST, M.-L. ERIKSSON, H. SJÖRGEN, Characteristics of Collaboration in Product Innovation in the Regional System of Innovation of East Gothia, „European Planning Studies" 2002, nr 5, s. 565.

2) Por. F. JANSZEN, G. DEGENAARS, A Dynamic Analysis of the Relations Between the Structure and the Process of National Systems of Innovation Using Computer Simulation: The Case of the Dutch Biotechnological Sector, „Research Policy” 1998, vol. 27, s. 37; P. COOKE, M.G. URANGA, G. ETXEBARRIA, Regional Innovative Systems: Institutional and Organisational Dimension, „Research Policy" 1997, nr 26, s. 475.

3) M. FRITSCH, Co-operation in Regional Innovation Systems, „Regional Studies” 2001, nr 35.4, s. 305.

4) Szerzej A. MARSHALL, Principles of Economics. An Introductory Volume, 8th edition, Macmillan, London 1920/ 1890, s. 565.

5) Por. A. AMIN, A. MALBERG, Competing Structural and Institutional Influence on the Geography of Production in Europe, [w:] Post-Fordism: A Reader, A. Amin (red.), Blackwell Publisher, Oxford 1994. Por. OECD: Cities and Regions in the Learning Economy, Published by the Centre for Educational Research and Innovation (CERI), OECD 2001.

6) Szerzej M. PIORE, C. SABEL, The Second Industrial Divide: Possibilities for Prosperity, Basic Books, New York 1984.

7) Szerzej na temat ewolucji szkół teorii firmy w pracy T. GRUSZECKIEGO, Wspótczesne teorie przedsiębiorstwa, PWN, Warszawa 2002

8) Takie rozwiązanie okazało się skuteczne w Irlandii.

9) Szerzej J. MARCEAU, Divining Directions for Development: a Co-operative Industry-government-public Sector Research Approach to Establishing $R \& D$ Priorities, „R\&D Management" 2002, nr 32.

10) Szerzej D. STURN, Decentralized Industrial Policies in Practice: The Case of Austria and Styria, „European Planning Studies" 2000, vol.8, nr 2.

11) P. MASKELL, A. MALMBERG, The Competitiveness of Firms and Regions, „Ubiquitification” and the Immportence of Localized Policy, „Research Memoranda” 1999, nr 00-23, Maastricht University, Merit 1999. Ponadto szerzej zjawiskiem kooperacji autor zajmuje się w kolejnym punkcie.

12) H. ALM, M. McKELVEY, When does Cooperation Positively or Negatively Affect Innovation? An Exploration into Turbulent Waters, Discussion Paper nr 39 at CRIC (Center for Research on Innovation and Competition), University of Manchester, Manchester 2000.

13) R. STERNBERG, Innovation Networks and Regional Development - Evidence from the European Regional Innovation Survey (ERIS): Theoretical Concepts, Methodological Approach, Empirical Basis and Introduction to the Theme Issue, „European Planning Studies” 2000, vol. 8, nr 4, s. 392. 
14) Por. op.cit.; por. P. COOKE, M.G. URANGA, G. ETXEBARRIA, Regional Innovative Systems: Institutional and Organisational Dimension, „Research Policy” 1997, $\mathrm{nr} 26$.

15) Szerzej S.A. ROSENFELD, Just Clusters. Economic Development Strategies that Reach More People and Places. Regional Technologie Strategies, Carrobor NC, wrzesień 2002 , s. 32.

16) G. DOSI, Some Notes on National Systems of Innovation and Production, and Their Implications for Economic Analysis, [w:] D. ARCHIBUGI, J. HOWELLS, J. MICHIE (red.), Innovation Policy in a Global Economy, Cambridge University Press, Cambridge 1999, s. 35-48.

17) Szerzej R. AROCENA, J. SUTZ, Changing Knowledge Production and Latin American Universities, „Research Policy" 2001, vol. 30, s. 1221.

18) F. MEYER-KRAHMER, U. GUNDRUM, Innovationforderung im landlichen Raum, „Raumforschung und Raumordnung" 1995, nr 49, s. 177-185.

19) A.B. JAFFE, Real Effects of Academic Research, „American Economic Review" 1989, nr 79, s. 957-70. L. ANSELIN, A. VARGA, Z.J. ACS, Local Geographic Spillovers Between University Research and High Technology Innovation, „J. Urban Economy” 1997, nr 42, s. 422-48.

20) L. SOETE, A. ARUNDELL, An Integrated Approach to European Innovation and Technology Diffusion Policy, Commission of the European Communities, Brussels 1993.

21) D. STURN, op.cit., s. 170.

22) Op.cit.

23) CH. EDQUIST, M.-L. ERIKSSON, H. SJÖRGEN, Characteristics of Collaboration..., op.cit., s. 564.

24) P. COOKE, Introduction: Origins of the Concept, [w:] H.J. BRACZYK, P. COOKE, M. HEIDENREICH (red.), Regional Innovation Systems: The Role of Governance in a Globalized World, PA: UCL, London and Philadelphia 1998.

25) R. STERNBERG, Innovation Networks..., op.cit., s. 392.

26) Od 1994 roku ponad 100 regionów w Unii Europejskiej skorzystało z tych programów.

27) R. STERNBERG, Innovation Networks..., op.cit., s. 392

28) R. HUGGINS, Competitiveness and the Global Region: The Role of Networking, Paper prepared for the Regional Studies Association Conference on Regional Futures: Past and Present, East and West, Mass, Gothenburg 1995.

29) J. GANCARCZYK, M. GANCARCZYK, Konkurencyjność skupisk przemystu (clusters) - od korzyści zewnętrznych do korzyści sieci, „Studia Regionalne i Lokalne” 2002, nr 2-3, s. 80.

30) G. GRABHER, D. STARK, Organizing Diversity: Evolutionary Theory, Network Analysis and Postsocialism, „Regional Studies" 1997, nr 31, s. 533-44.

31) A.T. THWAITES, Some Evidence of Regional Variations in the Introduction and Diffusion of Industrial Products and Processes within British Manufacturing Industry, „Regional Studies” 1982, nr 16, s. 371-381; N. ALDERMAN, Predicting Patterns of Diffusion of Process Innovation within Great Britain, Paper presented to the Twenty-Fifth European Congress of the Regional Science Association, 27-30 sierpień 1985 Budapest; M.M. FISCHER, Innovation, Diffusion and Regions. Chapt. 5, [w:] A.E. ANDERSSON, D.F. BATTEN, C. KARLSSON (red.), Knowledge and Industrial Organization. Springer, Berlin, Heidelberg, New York 1989, s. 47-61.

32) Szerzej A. FRENKEL, Barriers and Limitations in the Development of Industrial Innovation in the Region, „European Planning Studies” 2003, vol. 11, nr 2, s. 117. 